KAZIMIERZ JAREMCZUK ANNA MAZURKIEWICZ ANNA MOLTER

\title{
Cultural determinants of attitudes toward \\ career
}

Professor Kazimierz Jaremczuk Subcarpathian Association of Organization and Management

Ph.D. Anna Mazurkiewicz

Subcarpathian Association of Organization and Management University of Rzeszów

M.Sc. Anna Molter Subcarpathian Association of Organization and Management

\section{Introduction}

A new type of career is developed contemporary. It changes the employee's relationship with an organization and is attributed to the "employability" itself (Baruch 2004, p 62). Processes within the organization's environment as well as its center require the change in the employer's approach to the employee. The employer-employee relationships should be characterized by, among others, openness, partnership and flexibility as well. It fosters the labor market skills development, useful while the cooperation with the organization will be completed. Constant changes we are living in, causes that the traditionally understood career i.e. of a linear character, is replaced by the protean career, a career without boundaries. The choice of a particular career path is the result of many choices between different values, what is, in majority, culturally determined process.

The aim of the article is to describe the role of organizational culture in formation of attitudes toward career. In the elaboration the career itself has been interpreted with a particular emphasis on its contemporary understanding. The issue of values internalization has been 
focused on. To organizational culture's importance in the career development has been given consideration here - a career in the subjective perspective i.e. the identification with a professional group, as well as perceived from both the organization's and the environment's perspective as well.

\section{The notion of career}

The notion of career in literature is interpreted variously. Career may be understood as (Miś 2007, pp. 19-20):

1. Profession, occupation - in this context, it relates to the professions characterized by clarified, defined career's development path, as a sequence of positions. A career in this interpretation is related to displacements.

2. Advancement, which refers to both external and internal aspects. In this interpretation, career is realized as a result of getting the added value - e.g., a higher position, more decision making opportunities as well as a sense of fulfillment and satisfaction.

3. The sequence of work done by a man in the course of their working lives. In this context, the career is limited to professional activity and therefore constitutes an attribute of every working man. It cannot be related to non working population, which makes this interpretation significantly limited.

4. Sequence of role-oriented human undertakings. This interpretation goes beyond the professional activity, concerns role. It is independent of any organization.

Career therefore, depending on the adopted perspective, may involve either working or whole life. It can be seen as an organization's attribute, involves the objective interpretation. It concerns the behavior of the entity then. On the other hand, the career itself can be treated as a human feature. The attitude of an individual is analyzed here, therefore, the interpretation is subjective. Holistic career is interpreted i.a. by D. Super (quoted in: Miś 2007, pp. 21-22). He argued that the career itself is related to the man's whole life. The roles performed and events taking place in one's life affects the work done by them.

Career has an internal dimension - which means individual's idea of the professional career, own role in it, personal plans and aspirations. Such perception, according to M. Driver (after Derr, Laurent 1989, p. 454), is dependent on cognitive style and helps to make choices of a long - term career. Therefore, the values important for individuals are significant - two people who perform the same sequence of work at the same place and time, may feel different about the same events and they may have a sense of success or failure (Bańka 2007,

Cultural determinants of attitudes toward 
p. 14). Career is defined personally and profession is the context in which it is executed (Banka 2007, p. 14). According to the above interpretation career of every human being is unique.

On the other hand, the external career's dimension is more objective, reflects the real constraints and opportunities in the organization. It addresses the following issues: realities, constraints, opportunities and professional sequence (Derr, Laurent 1989, p. 455). Outside career is interpreted in the organizational context, actions undertaking within organization towards people developing their professional career.

Both dimensions are interrelated as they influence each other significantly. The essence of an inside career is in an individual career's concept in both organizational and professional context as well, while in an outside career the importance is in organizational and therefore professional context itself.

Contemporary changes, variables and uncertain, turbulent-called environment, led to significant structural changes within organizations and consequently, to changes in the approach to career. The long-term contract was replaced by the short-term transactions. The contract is "renewable" as it takes the current organization's needs into account. It constitutes this type of career that takes the transition between many organizations into consideration and involves frequent changes in specializations and/or employment forms' as well. The employees develop their own career and take the full responsibility for that process.

New models of career take into account different choice opportunities - vertical, horizontal career achievement or directed at other - individual - goals. Career paths are created in the time and space, which are considered as beneficial and suitable by a given person. Also, career direction and interpretation of success have individual dimension. This context stresses the importance of both protean and boundaryless career.

Protean career is referred to as managed by a person, not by an organization itself. It is based on individually defined targets, covering the entire space, drive not by the objective, e.g. salary or power, but the psychological success (Briscoe, Hall 2006, p. 6). It is identified by a frequent change, inventiveness and own independent work (Hall 2002, p. 4).

This approach is focused on an independent career's management perspective, providing the guidance for an action. In this context, it recalls the attitude that includes a cognitive (a set of beliefs about career), the evaluation (being "good" or "wrong" for a person's career) as well as behavioral (tendency to act or behave in a certain way) components. Thus, the protean career is a way of thinking about a career. More precisely it is the attitude towards a career that reflects 
freedom, self-management and career choices based on personal values (Briscoe, Hall 2006, p. 6).

Contemporary, due to the increasing penetration of organization's boundaries, a career without boundaries is taken into consideration. Boundaryless career is described as unlimited, unrelated to one organization, not characterized by an sequence ordered, marked to a lesser extent by vertical coordination and stability. It is the opposite to organizational career that is developed in the framework of a single employment (Briscoe, Hall 2006, p. 6).

Both, the traditional linear career model, as well as contemporary models depict the extreme perspectives of career perceiving. Although in the milieu of modern organizations numerous changes occurred, many of them are still operating in a relatively stable external environment and apply proven management strategies. At the same time and in the past the psychological contract was not completely fixed.

Career is the reason of human actions that result from the accepted hierarchy of values in a given society (Bauman 1965, p. 21). Therefore, career should be seen, from the perspective of an individual and from an organizational point of view, in addition social environment should be taken into consideration.

\section{Premises of values internalization as the career's justification}

In relation to the above reflections, up to date but undervalued management concept by P.E Slater and W.G. Bennis (Slater, Bennis 1974) has an implementation character as well. It is expressed in terms of internalized values that drive employee's behaviour in constant situation volatility. These values are identified as: 1) full and free communication, independent of power and professional position 2) consensus as the solution, rather than compromise and concessions under duress 3) professional competence and knowledge as the power to influence, rather than personal whims and personal authority 4) atmosphere that liberates the emotional expression and stimulates a task - oriented behaviour 5) person oriented approach, assuming the inevitability of conflict between both organization and employee as well. It allows its rational solution (Slater, Bennis 1974, p. 18).

Management concept by P.E Slater and W.G. Bennis accepts employees' selfdefinition in the will's acts as well as undertakings' self-determination. Identified as actions' self-determination freedom manifestation (freedom of action) is the dependence from the external constraints that result from the organizational, social and cultural conditions. In particular, it is a freedom from physical

Cultural determinants of attitudes toward 
restraint, repression as well as personal and institutional aggression. Freedom of action may occur when the employee perceives the differences in terms of capacity to act and may choose a certain specific career according to their own values and goals. Otherwise, an employee must fulfil the necessary conditions to act, supported by the free, self-determined action's entity.

However, values' category identification as the employee's objectives is, in a consequence, the internalization process. In its result heteronymous values are converted into autonomous ones, that in accordance with the literature, do not require any control.

Primarily, the employee's internalisation of values is the formation of appropriate career conditions ${ }^{1}$. Certain conditions must be fulfilled in order to real, full internationalisation process to be completed:

- in the internalization process, an employee is a fundamental value, the creator and the subject to the values' influence,

- the values control employee's behavior, active approach,

- internalized values, in accordance with employee's value system, determine the motivation structure,

- internalized values define duties' content and so create the action's objectives,

- the internalization process explains, that not only the organization's structure but also en employee shapes their behavior. The structure reflects an action, so it is appropriate to the conscious and unconscious processes in employee's behavior,

- at some appropriate relationship's development the community goals can be found; therefore certain conflicts can be resolved by reference to common values, which creates the possibility of redefinition of e.g. career.

The reflections above show, that the values' understanding, experience, acceptance, recognition as well as the obedience is within internalization's essentials. It is particularly shown in management concept by P.E Slater and W.G. Bennis. Amongst these essentials, there is also an employees' ability to create values as a result of a certain states' knowledge, multiple needs', aspirations' and desires' discernment as well as acceptance of already operating, socially accepted and experienced within internalization process value system. Therefore, the ability to conscious creation, self-creation and self-improvement is shaped in the internalization process. The employee operates in symbiosis with its own

1 Appropriate - i.e. depicted a common good. The danger of treating people worse than they really deserve will decrease and approach zero then. The common good constitutes the community, as it creates the conditions for a common existence (Wojtyła 1986, p. 32). 
dual, both individual and social nature. Otherwise, an employee's specific behaviour's act is defined by both social-organizational and cultural situation, as well as the specificity of personality's structure. However, despite the fact, that certain personality's features are the result of environmental influence, an employees' personality structure is autonomous because of its connections with the body's needs and the uniqueness of individual's life experience, manifested, in particular, in the career's development process.

\section{Career from the organizational culture's perspective}

The organizational culture's perspective is one of the possible to identify career's cultural determinants. Organizational culture determines "the meaning space" (Zachariasz 2001, pp. 27-43, 187), creates a specific employees' operational context (information source), in which the arrangement of basic meanings, attributed to organizational practice, as well as attitudes and beliefs towards reality are established. They are accepted ways of doing things and problems solving (Czubasiewicz 2012, p. 117) as well as the rules driving the relationships (Kuc, Moczydłowska 2009, pp. 360-361).

In the most basic sense, the organizational culture, as a system of collectively shared meanings (information) creates an idea of what the organization should be and how it should operates due to its strategy. In this sense, the organizational culture can be understood as an area of soft management within the organizational behavior shaping at the individual, team and organizational level (Sparrow 2012, p. 29). It should be emphasized that the "real organizations do not generate autonomous cultures" (Sułkowski 2005, p. 82). Both inside and outside organizational determinants are interpreted as a "form of cultural adjustment ", proper to a given organization.

Under the integrated approach, a group of variables (Konecki 1992, p. 6) should be taken into account while the organizational culture is identified. These variables are of outside organizational character, of axiology and standard related social and cultural surrounding character (independent variable), of an inside organizational character (the dependent variable determined by both the strategy and structure) and may be also perceived from the entity's (individual employee's) point of view. It influences the perception and understanding of the organization's situation by an entity. It is assumed that these systems determine each other - resulting in the transformations in the sphere of meanings that relate to the phenomena (processes), things (the object of work) and men (interaction of individuals towards common goals/tasks). This system determines a culture

Cultural determinants of attitudes toward 
based on the organization's objectives and therefore, reflects the actions and implementation methods (Robbins, DeCenzo 2002, p. 253). Development of an appropriate organizational culture is understood as communication process, in which the rules and standards of operation are set (Sikorski 2009, p. 298).

Organizational culture has got behavior's both regulating and controlling function with the use of internalized values and norms (Aniszewska 2007, p. 14). This means that the organizational culture, integrated with a management system, acts as a kind of filter, "which makes observed events, objects, activities and communications meaningful" (Purgał-Popiel 2009, p. 42). Thus, from the management point of view, organizational culture has an essential function in the behavior's formalization (Bańka 2005, p. 315). In social constructed social coercion's dimension, it determines the degree of the freedom of action (opportunities - duties, the scope of sensitivities and constraints), carrying different types of sanctions, as lack of approval, stigma , exclusion, etc. (Czerska 2012 , p. 220).

Culture codetermines interpretative framework for organizational practice. In this sense it shapes career's social perception, that is not without significance for guiding the employee's professional activity.

Cultural determinants of once career should be identified with the use of already recognized variables that co-determine specific configuration for the specific organizational culture in the value-standard-practice system. In this sense it is possible to specify the cultural career's conditions in:

- a person's perspective,

- a professional group's perspective,

- an organizational (including the organizational culture) perspective,

- an organization's external surrounding's perspective.

This treatment is only to stratify the factors that stay together in a mutual relationship and often drives the individual actions in the career development, its perception, satisfaction and the attitude to success.

\subsection{Careers at the personal perspective}

Careers associated with a particular person assumes an individual assumption about the unique quality of each man's career. The personal perspective lets ones to bind the quality of life, job satisfaction, as well as approach to professional success and its social reception. The attitude and profession's choice, amongst the career is implemented are conditioned by a set of a personality's factors, subjective as a self-esteem (capabilities, 
limitations, abilities), attitudes, inner value system, aspirations and the degree of both satisfaction and importance associated with a self-development and a measure of success. "Subjective, personal accentuating" of a career shows the integral relationship of a personal development. It is associated with the career's construction, meaning that the person associates with success, motivation to work, the need for inner satisfaction and a choice of route of its implementation (Cybal-Michalska 2012, pp. 196-201).

\subsection{Career and professional group}

Personal and social perception of a career may be identified by the reference to the identification framework, that is linked to a specific profession. It constitutes a practice context, gives meaning, defining and legitimizing the repertoire of behaviors and standards for evaluation. Professions use the "good practice" internal evaluation criterion through, e.g. acceptance of certain professional rules. Unique employee's career can be realized in a particular professional group amongst the projection of a "professional identity" is made. Both socialization and identification processes that occur within a professional group, allow the identification of operational principles, rules concerning the professional practice, ethics, current patterns of action and careers' projection as well. The professional practice is a subject to constant changes (including cultural ones), modifying the work's content and its pragmatic character. The content of professional identity, according to Ł. T. Marciniak (2010 , pp. 182-183), defines: professional self-definition sets, professional interpretative profession's framework, the situation's definition set as well as the repertoire of interactive strategies relating directly to the mode of action.

\subsection{An organizational (including the organizational culture) perspective}

Organization sets the framework for the specific profession identity development, i.e., sets the framework for identification in the normative and postulating sense, defining the rules and "good practice" standards. In this sense, amongst the organization limits, both identification and professional socialization processes, professional career's projection, basic values and assumptions associated with "good practice" are identified. Changes to the work's content - professional practice $\mathrm{w}$ amongst the organization's framework is very often associated with changes in organizational culture (Marciniak 2010, p. 183). The consequences of contemporary changes in the formula binding the

Cultural determinants of attitudes toward 
organization with employees are contemporary in question. The transition from the traditional career understanding, in the linear, professional sense for the spiral and transitional career (Januszkiewicz 2012, p. 109), causes a change in the internal relationship's architecture. In this sense, the organizational culture is, in a axiology and standard-related layer the basis of employee-organization contracts. (Aniszewska 2004, p. 10).

\subsection{External perspective}

Organizations as socially isolated co-operation system, operate within the community and in this sense they are "derived from environmental cultures from which the majority of employees derive from" . According to G. Hofstede (2000, p. 268), it should be noted that while the organizations' goals are different, the the environment's unity with the values should be noticed. In this sense, the "career ethos" is closely connected with the society recognized values, in its culture. It is deeply rooted in the social consciousness (Cybal-Michalska 2012, p 195). Career as a social phenomenon is associated with socially made projections - economy and its associated processes (cultural, political, economic, institutional and regulatory processes) (Koźminski, Zagórski 2012, p. 55) evaluation and perception as well as socially duly attitude to success (Sikorski 2008, p. 63).

\section{Conclusions}

Due to the contemporary changes, a new type of career is developed. Flexibility in the labor market often requires changes in both employee's location and work nature. It affects career itself. A new type of psychological contract between the employee and the employer as well as the relationship between superiors and subordinates are created. Long-term employment is replaced by the short-term transactions, resulting in a change of employee's career building strategy.

Career, on the one hand, is a "property" of an individual. Individual is responsible for their choices in life, thus for their own career. Career refers primarily to professional activities, which are a source of identity, creativity, life's challenges, as well as the status, establishing and maintaining social relationships (Baruch 2004, p. 59). Career development is a challenge and at the same time it provides a sense of achievement and satisfaction (fulfillment, realization). On the other hand, career is planned in the organization and also managed by it. Thus, the organizational structure of an organization, processes that take place in it as well as culture affect career of an individual. 
The values resulting from experience gained by an individual as a result of functioning in a given society, which the individual brings to the organization, are also important. The system of values is a "frame" (Bauman 1965, p. 27), in which a person fits their individual career and on which the careers in the organization are managed. The hierarchy of values of a society affects individual and group goals. Culture is therefore an important determinant of a professional career.

The considerations are the basis for the adoption of a certain pattern for further research: value - the norm - practice. This system involves feedback in the context of symbolic systems and it defines the process of giving sense and meanings to organizational activities in communication interactions. In this sense, the cultural context of the community, understood as J. Kmita, as a set of normative and directive beliefs (Bonecki 2012, p. 194) having axiological importance (duty and obligation) is basis and justification for the actions of institutionalized activities i.e. organizations and within them certain professional groups. Organizational culture as a resource of information (descriptive knowledge), provides a normative and postulative framework (goals) for shaping attitudes and behavior - organizational activity. The theoretical and application value is gained by the assumption of the role of the dominant narrative in shaping organizational culture, acting for the participants of the organization as a landmark and cognitive perspective. It should be emphasized that the informal communication (vertical and horizontal) is the primary source of meanings linked with the organizational reality, in the sense it significantly shapes the perception of career and success in a given organization. The practice determines the scope of actual types of workers' behaviors, in contrast to the declared level of standards and action patterns. In this sense, the context of the practice of a profession, takes place in a sort of "communication network" (informal) structuring activities in which a process takes place of reconstructing the justifications and own career selfdefinition, the verification process and often a change in patterns of actions that have already "worn out". This scheme must be analyzed taking into account the diverse perspectives represented by different disciplines of science.

\section{Summary}

\section{Cultural determinants of attitudes toward career}

This article is focused on the culture's influence on the employees' career. The career itself has been interpreted with a particular emphasis on its contemporary understanding. The issue of 
values internalization has been focused on. To organizational culture's importance in the career development has been given consideration here - a career in the subjective perspective i.e. identification with a professional group, as well as perceived from both organization's and the environment's perspective as well. In particular, the problem regards organizational culture as a derivative of the employees' environmental cultures.

Keywords: career, organizational culture, new type of career.

\section{Streszczenie}

Kulturowe uwarunkowania postaw wobec kariery zawodowej $\mathrm{W}$ artykule skoncentrowano się na zagadnieniu oddziaływania kultury na karierę pracowników. Dokonano interpretacji pojęcia kariery, ze szczególnym uwzględnieniem jej współczesnego rozumienia. Skoncentrowano się na zagadnieniu internalizacji wartości. Zwrócono uwagę na znaczenie kultury organizacyjnej w kształtowaniu kariery - kariery postrzeganej w perspektywie podmiotowej, jako identyfikację z grupą zawodową, postrzeganej z perspektywy organizacji oraz otoczenia. W szczególności problem dotyczy kultury organizacyjnej jako pochodnej kultur środowiskowych pracowników.

Stowa

kluczowe: $\quad$ kariera, kultura organizacyjna, nowy typ kariery.

\section{References}

1. Aniszewska G. (2004), Rola kultury organizacyjnej w zarządzaniu, „Przegląd Organizacji", nr 1.

2. Aniszewska G. (2007), Kultura organizacyjna w zarządzaniu, PWE, Warszawa.

3. Bańka A. (2007), Psychologiczne doradztwo karier, Print-B, Poznań.

4. Bańka W. (eds.) (2005), Zarzadzanie potencjałem społecznym w nowoczesnej organizacji, Novum, Płock.

5. Baruch Y. (2004), Transforming careers: from linear to multidirectional career paths Organizational and individual perspectives, "Career Development International", Vol. 9, No. 1.

6. Bauman Z. (1965), Kariera. Cztery szkice socjologiczne, ISKRY, Warszawa.

7. Bonecki M. (2012), Jerzy Kmita - interpretacja humanistyczna i społeczno- 
regulacyjna koncepcja kultury, „Filozofia Publiczna i Edukacja Demokratyczna" Tom I, nr 2.

8. Briscoe J.P., Hall D.T. (2006), The interplay of boundaryless and protean careers: Combinations and implications, "Journal of Vocational Behavior", Vol. 69.

9. Cybal-Michalska A. (2012), Kariera jako „własność" jednostki - rozważania teoretyczne nad definicja credo, „Kultura-Społeczeństwo-Edukacja”, nr 1.

10. Czerska M. (2012), Uwarunkowania kulturowe zachowań w organizacji, in: R. Rutka, P. Wróbel (eds.), Organizacja zachowań zespołowych, PWE, Warszawa.

11. Czubasiewicz H. (2012), Komunikacja społeczna - wpływ na zachowania w organizacji, in: R. Rutka, P. Wróbel (eds.), Organizacja zachowań zespołowych, PWE, Warszawa.

12. Derr C.B., Laurent A. (1989), The Internal and External Career: A Theoretical and Cross-Cultural Perspective, w: M.B. Arthur, D.T. Hall, B.S. Lawrence (eds.), Handbook of Career Theory, Cambridge University Press, Cambridge.

13. Hall D.T. (2002), Careers In and Out of Organizations, Foundations for Organizational Science, A Sage Publications Series, Thousand OaksLondon-New Delhi.

14. Hofstede G. (2000), Kultury i organizacje. Zaprogramowanie umystu, PWE, Warszawa.

15. Januszkiewicz K. (2012), Elastyczność zasobów ludzkich - konsekwencje społeczne, "Acta Universitatis Lodziensis, Folia Oeconomica”, nr 265, Łódź.

16. Konecki K. (1992), Kultura organizacyjna japońskich przedsiębiorstw przemysłowych, Studium socjologiczne, Uniwersytet Łódzki, Łódź.

17. Koźmiński A. K., Zagórski K. (2011), Wyobraźnia ekonomiczna w Polsce, "Studia Socjologiczne", nr 2.

18. Kuc B. R., Moczydłowska J. M. (eds.) (2009), Zachowania organizacyjne podręcznik akademicki, Difin, Warszawa.

19. Marciniak Ł. T. (2010), Konstruowanie tożsamości zawodowej: procesy odniesienia i rozróżnienia, w: K. T. Konecki, A. Kacperczyk (eds.), Procesy tożsamościowe. Symboliczno-interakcyjny wymiar konstruowania ładu i nieładu społecznego, Uniwersytet Łódzki, Łódź.

20. Miś A. (2007), Koncepcja rozwoju kariery zawodowej organizacji, Wyd. Uniwersytetu Ekonomicznego w Krakowie, Kraków.

21. Purgał-Popiela J. (2009), Relacje między kultura organizacyjna a kapitałem intelektualnym, w: M. Juchnowicz (ed.), Kulturowe uwarunkowania zarządzania kapitałem ludzkim, Wolters Kluwer Polska, Kraków - Warszawa.

22. Robbins S.P., DeCenzo D.A. (2002), Podstawy zarządzania, PWE, Warszawa.

23. Sikorski C. (2008), Stosunek do sukcesu jako podstawa kultury organizacyjnej, "Zarządzanie Zasobami Ludzkimi", nr 3-4.

24. Sikorski C. (2009), Odkrywanie wzorów kulturowych w procesie ksztattowania kultury organizacyjnej, „Annales UMCS”, Vol. 19. 
25. Slater P.E., Bennis W.G. (1974), Democracy is inevitable, w: K. Davis (ed.), Organizational Behavior, McGraw-Hill, New York.

26. Sułkowski Ł. (2002), Kulturowa zmienność organizacji, PWE, Warszawa.

27. Wojtyła K. (1986), Miłość i odpowiedzialność, KUL, Lublin.

28. Wróbel P. (2012), Oczekiwania organizacji wobec jej pracowników, w: R. Rutka, P. Wróbel (eds.), Organizacja zachowań zespołowych, PWE, Warszawa.

29. Zachariasz A.L. (2001) Kultura jej status i poznanie, Uniwersytet Rzeszowski, Rzeszów. 